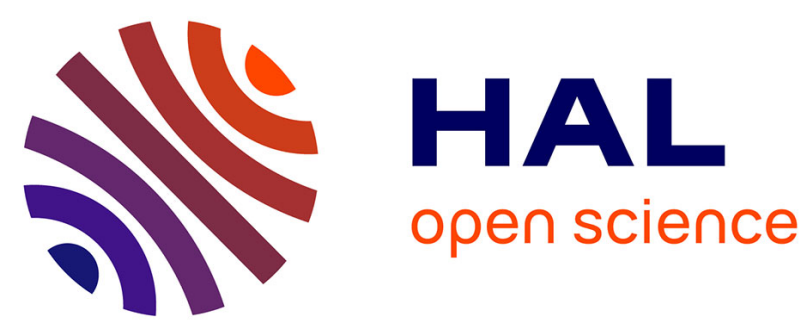

\title{
The Impact of Organizational Culture on Performance Measurement System Design, Implementation and Use: Evidence from Moroccan SMEs
}

\author{
Meriam Jardioui, Patrizia Garengo, Semma El Alami
}

\section{To cite this version:}

Meriam Jardioui, Patrizia Garengo, Semma El Alami. The Impact of Organizational Culture on Performance Measurement System Design, Implementation and Use: Evidence from Moroccan SMEs. IFIP International Conference on Advances in Production Management Systems (APMS), Sep 2017, Hamburg, Germany. pp.553-559, 10.1007/978-3-319-66923-6_65 . hal-01666219

\author{
HAL Id: hal-01666219 \\ https://hal.inria.fr/hal-01666219
}

Submitted on 18 Dec 2017

HAL is a multi-disciplinary open access archive for the deposit and dissemination of scientific research documents, whether they are published or not. The documents may come from teaching and research institutions in France or abroad, or from public or private research centers.
L'archive ouverte pluridisciplinaire HAL, est destinée au dépôt et à la diffusion de documents scientifiques de niveau recherche, publiés ou non, émanant des établissements d'enseignement et de recherche français ou étrangers, des laboratoires publics ou privés. 


\title{
The impact of organizational culture on Performance measurement system design, implementation and use. Evidence from Moroccan SMEs.
}

\author{
Meriam Jardioui ${ }^{1}$, Patrizia Garengo ${ }^{2}$, Semma El Alami ${ }^{1}$ \\ ${ }^{1}$ Laboratory IM2I, Hassan I University, Settat, Morocco \\ m.jardioui@uhp.ac.ma \\ ${ }^{2}$ Department of Industrial Engineering, University of Padua, Padua, Italy
}

\begin{abstract}
Several earlier studies have viewed organizational culture (OC) as a key factor for performance measurement systems (PMS), yet its role is not well understood and the reviewed literature indicates a gap in articles describing the relationship between various types of OC and PMS. Thus, the following study sets out to explore how OC type impacts PMS design, implementation and use. The investigation is carried out using the case study methodology in two Moroccan manufacturing SMEs. Our findings suggest that there is a relationship between OC type and PMS life cycle.
\end{abstract}

Keywords : performance measurement system, organizational culture, small and medium enterprises, semi-structured interviews

\section{Introduction}

The structure of today's business context is changing promptly, generating an important deal of uncertainty. This environment obliges firms, especially small and medium-sized enterprises (SMEs), to be more innovative and to constantly review their processes and practices in order to survive on the current competitive environment. This means that they must keep a close eye on their performance [1]. Therefore, performance measurement systems (PMSs) are considered as a means to gain competitive advantages and continuously react and adapt to external changes [1].

Although research studies underline the key role of PMS in supporting managerial growth, particularly in SMEs [2], a lot of initiative of its implementation failed and the reasons for failure are varied and of diverse nature[3]. Among those important factors figures organizational culture [4]. According to Bourne (2005), organizational culture is one of the important drivers of successful PMS implementation [3].

adfa, p. 1, 2011.

(c) Springer-Verlag Berlin Heidelberg 2011 
Organizational culture has been defined as the attitudes,values, beliefs and behaviours that represent an organisation's working environment, organisational objective, and vision[5]. Kandula (2006) once remarked that due to differences in organizational culture, the same strategies do not yield the same results even if two organizations belong to the same industry and opertate in the same geographical context [6]. Although the significant and definite influence of organizational culture on the management of organizations is recognized by literature [7], the research stream fit with the impact of this factor on PMS is still lacking and the studies investigating the impact of the main types of organizational culture on PMS are not enough studied [8]. In order to fill this research gap, and taking into account the growing economic relevance of developing countries, this paper investigates the impact of organizational culture on PMS design, implementation and use in the Moroccan SMEs.

The remainder of this paper is organized as follows: in the next section we will discuss the relationship between performance measurement system and organizational culture from the opinion of previous literature. Subsequently, we present the methodology of the study and the findings, followed by a discussion of the results and the conclusion.

\section{Performance measurement system and Organizational culture}

Through a systematic literature review of issues affecting how companies manage through measures Franco-Santos and Bourne [9] have found out that factors influencing performance measurement system (PMS) are divided in two main categories; process factors which are concerned with different phases of PM systems (i.e., design, implementation, use and update) and contextual factors which emphasize the environment in which the PM system operates. Moreover, they split contextual factors into internal factors relating to organizational context and external factors concerning the environment and industry characteristics.

Furthermore, the PM literature underlines the importance of aligning PMS with organizational culture or the users' cultural preference [10]. Franco and Bourne for example, suggest that organizational culture that emphasizes teamwork, ownership of problems, risk-taking, entrepreneurship, continuous improvement and encourages performance discussion and analysis without punishing people's errors are critical to success of PMS. However, literature did not clearly provide how alignment between the organizational culture and the PMS should be developed [9].

Jwijati \& Bittitci (2015), in turn, reviewed the research stream fit with the impact of organizational culture on performance measurement systems, and have noticed that 
this area of research is still lucking [8]. Moreover, they categorize the research studies into three categories. The first stream discusses the impact of organizational culture on PMS generally. Bittitci et al., $(2004,2006)$ remark that the relationship between organizational culture and PMS is dyadic [11][12]. The second stream suggests that a successful implementation of PMS require a particular organizational culture, in this case, we found Bourne et al. (2002) who believed that a "paternalistic culture" is a key success for PMS implementation [13]. Assiri et al. (2006) suggested that a culture stimulating participation and involvement of all employees is considered as one of the main factors enhancing a successful implementation of PMS [14] and lastly De Waal \& Counet (2009) showed that a better implementation and use of PMS require a culture focusing on continuous improvement [15]. Finally, a third stream which links particular organizational culture components to PMS as Henri (2006) who demonstrated that there is a relationship between culture types and diversity of measurement and nature of use of PMS [16] and Mendibil \& Mac Bryde (2006) who suggested that organizational culture features could be a constraint for the design and implementation of PMS [17]. At last Jwijati \& Bititci (2015)have explored the relationship between PMS and the different type of organizational culture as suggested by the competing value framework [8]

As we see from the above, studies investigating the impact of all types of organizational culture on PMS in only one framework are almost inexistent.

\section{$3 \quad$ Methodology}

Previous research that has studied the impact of organizational culture on PMS used both qualitative and quantitative research methods. To achieve our purpose, the case study approach has been adopted, this method was chosen for two main reasons. Firstly, the research is explorative, as mentioned above, researches on the topic studied are still lacking. Further, the case studies have proven to be very useful for unveiling possible contingency effects and for finding empirically grounded explanations for them [18]. The criterion for choosing organizational cultures is based on Cameron \& Quinn's competing values framework [19] which suggests that organizational culture could be organized and described along two dimensions: structure and focus. The structure dimension depicts the organization's flexibility or control in dealing with emerging conditions. The focus dimension represents the focus of the organization and if this focus is internal or external to the organization. Based on those dimensions, literature discerns between four types of organizational culture: market, adhocracy, clan, and hierarchy. The access to information to identify organization's basic cultural assumptions for selecting significant firms and carrying out our research wasn't easy. Thus, initially two companies representing the dilemma of control versus flexibility 
were investigated. Both case studies were indigenous SMEs, privately owned and have industrial background.

In preparation for the company visits, a research protocol was designed based on the "performance measurement system phases development" as proposed by Bourne et al., (2000) who suggest that the development of PMS could be divided into four main phases these are: design, implementation, use and review of performance measures [20] . For the design phase, the authors require two steps: identifying the key objectives to be measured and designing the measures themselves. Most of the literature in performance measurement mentioned that the measures should be derived or aligned to the strategy or organizational goals. Regarding the implementation phase, Bourne define it as "the phase in which systems and procedures are put in place to collect and process the data that enable the measurements to be made regularly" [20]. The use of performance measures can be split in two main subdivisions: assessing the implementation of strategy and challenging the strategic assumptions. As to the review phase, Bourne et al., (2000) underline that is required to make certain that the PM system is dynamic enough to reflect the changing business environments [20].

The research protocol was discussed between authors and elaborated upon and then sent by email to managers interviewed. One researcher moved on sites for interviewing general and middle managers each separately, The length of each interview depended on achieving the aim of the research and answering each question, ranging from 45 to $90 \mathrm{~min}$. data were collected through document review, participant observations, and semi-structured interviews. Document review included company site, documents afforded by the organization. Participant observation implied sitting in meetings with top management and their staff. Interviews were used to get input from different actors about aspects of design, implementation, and use of PMS in semistructured style. The interviews were recorded and transcribed subsequently and local languages ( French and Arabic) were the languages employed in each company.

It should be mentioned that in order to identify each organization's culture, we chose the organizational culture assessment instrument (OCAI) supported by the competing value framework. This instrument consisted of six parts, each part consisted of 4 questions or rather four descriptions matched the definitions of the four culture forms as proposed by [19]. Interviewees were asked to distribute 100 points for each part depending on how alike the descriptions were to their organization. Using the OCAI, an organizational culture profile can be examined by establishing the organization's dominant culture type characteristics. This instrument has been tested in more than a thousand organizations and has been found to predict organizational performance. 


\section{$4 \quad$ Findings}

The organization culture of each case has been analyzed by the researchers qualitatively and the results are synthetized in Figure 1.

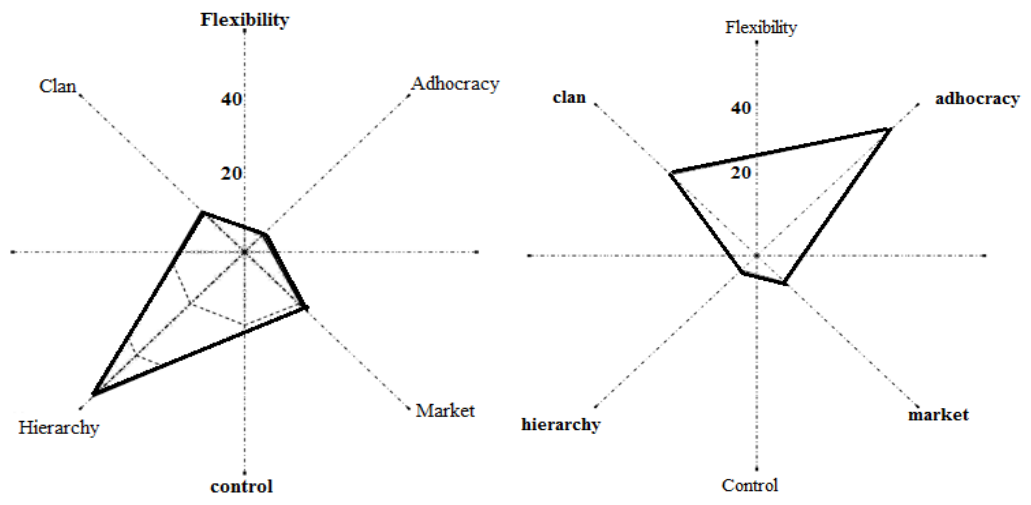

Fig. 1. Organizational culture type of the two companies

According to the results, the firm with a flexible culture tends to use more balanced performance measures, and uses PMS for aims such as learning, improvement and strategy implementation more than the firm which has a controlling culture and which tends to use PMS for aims such as monitoring and legitimization using financial measures. The table below presents a summary of our empirical evidences.

Table 1. - PMS design, implementation, and use across organizational cultures

\begin{tabular}{|c|c|c|c|c|}
\hline & \multirow{2}{*}{$\begin{array}{l}\text { Organiza- } \\
\text { tional cul- } \\
\text { ture type }\end{array}$} & \multicolumn{3}{|c|}{ PMS } \\
\hline & & Design & Implementation & Use \\
\hline $\begin{array}{l}\text { Campa- } \\
\text { ny A : } \\
\text { is a lead- } \\
\text { er in the } \\
\text { field of } \\
\text { battery } \\
\text { manufac- } \\
\text { ture in } \\
\text { the Mo- } \\
\text { roccan } \\
\text { market } \\
\text { with } \\
\text { almost } \\
180 \\
\text { employ- } \\
\text { ees and a }\end{array}$ & Adhocracy & $\begin{array}{l}\text { Measures natu- } \\
\text { re: } \\
\text { financial, pro- } \\
\text { duction process } \\
\text {, customer satis- } \\
\text { faction, learning } \\
\text { and improve- } \\
\text { ment measures } \\
\text { Identifying key } \\
\text { objectives: } \\
\text {-The perfor- } \\
\text { mance measures } \\
\text { are linked to the } \\
\text { company's } \\
\text { strategy. } \\
\text {-The strategy is }\end{array}$ & $\begin{array}{l}\text { Data Collection } \\
\text { performance data } \\
\text { (such as production } \\
\text { process data) are } \\
\text { collected using } \\
\text { specific software } \\
\text { Storage of Data } \\
\text { Data are stored in } \\
\text { an integrated infor- } \\
\text { mation system } \\
\text { Data distribution } \\
\text { Company distrib- } \\
\text { utes data using } \\
\text { visual management, } \\
\text { regular interdepart- } \\
\text { mental meetings }\end{array}$ & $\begin{array}{l}\text { Purpose of measures } \\
\text { - strategy implemen- } \\
\text { tation } \\
\text {-communication } \\
\text {-learning and im- } \\
\text { provement } \\
\text { Reviewing and act- } \\
\text { ing } \\
\text { on measures } \\
\text { - Performance } \\
\text { measures are re- } \\
\text { viewed monthly, } \\
\text { during a managerial } \\
\text { meeting (the meeting } \\
\text { include the top and } \\
\text { middle managers) }\end{array}$ \\
\hline
\end{tabular}




\begin{tabular}{|c|c|c|c|c|}
\hline $\begin{array}{l}\text { turnover } \\
\text { around } \\
200 \\
\mathrm{MDH} \text {. }\end{array}$ & & $\begin{array}{l}\text { explicit and } \\
\text { communicated } \\
\text { to all managers. }\end{array}$ & and online reports & $\begin{array}{l}\text { - there is an immedi- } \\
\text { ate intervention of } \\
\text { managers in case of } \\
\text { problem, } \\
\text { - there are not a } \\
\text { causal model }\end{array}$ \\
\hline $\begin{array}{l}\text { Campa- } \\
\text { ny B: } \\
\text { operates } \\
\text { in the } \\
\text { tippers } \\
\text { and } \\
\text { trailers } \\
\text { manufac- } \\
\text { turing } \\
\text { with } 54 \\
\text { employ- } \\
\text { ees and a } \\
\text { turnover } \\
\text { of } 76 \\
\text { MDH. }\end{array}$ & $\begin{array}{l}\text { Hierar- } \\
\text { chical }\end{array}$ & $\begin{array}{l}\text { Measures na- } \\
\text { ture: } \\
\text { financial, cus- } \\
\text { tomer satisfac- } \\
\text { tion } \\
\text { Identifying key } \\
\text { objectives: } \\
\text { The company's } \\
\text { strategy is } \\
\text { implicit, and the } \\
\text { performance } \\
\text { measures are } \\
\text { developed by } \\
\text { the top } \\
\text { management. }\end{array}$ & $\begin{array}{l}\text { Data Collection } \\
\text { data are collected } \\
\text { manually and using } \\
\text { Excel and ERP } \\
\text { Storage of Data } \\
\text { paper format and } \\
\text { use of ERP coexist- } \\
\text { ence to store data } \\
\text { Data distribution } \\
\text { Company distrib- } \\
\text { utes data by means } \\
\text { of formal and in- } \\
\text { formal face to face } \\
\text { meetings and online } \\
\text { reports }\end{array}$ & $\begin{array}{l}\text { Purpose of measures } \\
\text { control and monitor- } \\
\text { ing } \\
\text { Reviewing and act- } \\
\text { ing on measures } \\
\text { The lack of data and } \\
\text { traceability obstruct } \\
\text { the timely solution } \\
\text { of problems. }\end{array}$ \\
\hline
\end{tabular}

\section{Discussion and conclusion}

This study enhances the body of knowledge by providing theoretical insights and empirical findings regarding the impact of organizational culture and PMS design, implementation and use.

In adhocracy culture: we witnessed that performance measures are balanced and derived from strategy. The measures are used for purposes such as strategy implementation, engaging employees by integrating reward systems and regularly updating and reviewing PMS and for continuous improvement which is compatible with adhocracy culture's dynamic and entrepreneurial nature. Moreover, in order to provide necessary data for inter-managerial communication which help middle and top management to take and own decisions, an integrated information system, regular meeting with the use and support of graphs and charts were implemented.

In hierarchical culture: financial and customer measures which have been developed by the top management are used for control and monitoring purposes. The implementation is backed with the authority of the top management, most of data are collected manually which often make the information inaccurate and out of date and create a lack of traceability and consequently, obstruct the review and the update of the PMS. 
Given the fact that the aim of measurement is controlling, it is the top management who holds the information and takes decisions and communicates it to middle management. This suggests certain compatibility with the focus on formalization and the emphasis the hierarchical culture.

These findings imply that managers need to be aware of the values on which their firm relies before trying to design, implementing and using PMS or adapting organizational processes to foster accurate use. For example, it might be more simple for an organization having flexibility values to use PMS to focus organizational attention than for another having strong control values. Therefrom, before implementing a PMS, organizations are encouraged to define the use they are looking forward to better lead the design of the system toward the appropriate diversity of performance measures.

This study is subject to potential limitations that can be mentioned. It can be asserted that the empirical evidence is based on just two case studies and the results cannot be generalized, it need to be broadened notably by using quantitative methods. a more number of cases may be useful for future research, moreover, researchers could investigate broader aspects of performance measurement and management and other pairs of competing values or other cultures frameworks. For instance, research could tempt to determine the adequate fit between organizational values and performance measurement and management practices to improve organizational performance.

However, in spite of the limitations, we believe that this study is pertinent to academics and practitioners in the field of performance measurement and management. In one hand, the impact of organizational culture on PMS is a prevalent topic which needs to be examined more deeply from different perspectives. In other hand, Morocco, as a developing country, simultaneously experiences the global technological and competitive effects with the other developed countries, so practical importance and necessity of the studies on PMS and organizational culture can be evaluated more clearly.

\section{References}

1. Cocca, Paola, and Marco Alberti. "A framework to assess performance measurement systems in SMEs." International Journal of Productivity and Performance Management 59.2 (2010): 186-200.

2. Garengo, Patrizia, and Milind Kumar Sharma. "Performance measurement system contingency factors: a cross analysis of Italian and Indian SMEs." Production Planning \& Control 25.3 (2014): 220-240.

3. Bourne*, Mike. "Researching performance measurement system implementation: the dynamics of success and failure." Production Planning \& Control 16.2 (2005): 101-113. 
4. Jwijati, Ihssan M., and Umit S. Bititci. "Exploring the Impact of National Culture on Performance Measurement." IFIP International Conference on Advances in Production Management Systems. Springer Berlin Heidelberg, 2014.

5. Hofstede, Geert. Culture's consequences: International differences in work-related values. Vol. 5. sage, 1984.

6. Kandula, Srinivas R. Performance management: Strategies, interventions, drivers. PHI Learning Pvt. Ltd., 2006.

7. Garengo, Patrizia, and Umit Bititci. "Towards a contingency approach to performance measurement: an empirical study in Scottish SMEs." International Journal of Operations \& Production Management 27.8 (2007): 802-825

8. Jwijati, I., \& Bititci, U. S., The impact of organizational culture on the design and use of Performance Management Systems, Proceeding of the 22th International Annual EurOMA Conference", June 26th - July 1st, 2015, Neuchâtel, Switzerland

9. Franco-Santos*, Monica, and Mike Bourne. "An examination of the literature relating to issues affecting how companies manage through measures." Production Planning \& Control 16.2 (2005): 114-124.

10. Bourne, Mike, Mike Kennerley, and Monica Franco-Santos. "Managing through measures: a study of impact on performance." Journal of manufacturing technology management 16.4 (2005): 373-395.

11. Bititci, Umit S., et al. "Dynamics of performance measurement and organisational culture." International Journal of Operations \& Production Management 26.12 (2006): 13251350.

12. Bititci, Umit S., et al. "The interplay between performance measurement, organizational culture and management styles." Measuring Business Excellence 8.3 (2004): 28-41.

13. Bourne, Mike, et al. "The success and failure of performance measurement initiatives: Perceptions of participating managers." International journal of operations \& production management 22.11 (2002): 1288-1310.

14. Assiri, Ali, Mohammed Zairi, and Riyad Eid. "How to profit from the balanced scorecard: An implementation roadmap." Industrial Management \& Data Systems 106.7 (2006): 937 952.

15. de Waal, André A., and Harold Counet. "Lessons learned from performance management systems implementations." International Journal of Productivity and Performance Management 58.4 (2009): 367-390.

16. Henri, Jean-François. "Organizational culture and performance measurement systems." Accounting, organizations and society 31.1 (2006): 77-103.

17. Mendibil, Kepa, and Jillian MacBryde. "Factors that affect the design and implementation of team-based performance measurement systems." International Journal of Productivity and Performance Management 55.2 (2006): 118-142.

18. Garengo, Patrizia, Sai Nudurupati, and Umit Bititci. "Understanding the relationship between PMS and MIS in SMEs: an organizational life cycle perspective." Computers in Industry 58.7 (2007): 677-686.

19. Cameron, K. S. \& Quinn, R. E.,. Diagnosing and Changing Organizational CultureBased on the Competing Values Framework. Addison-Wesley : Longman. 1999

20. Bourne, Mike, et al. "Designing, implementing and updating performance measurement systems." International journal of operations \& production management 20.7 (2000): 754771. 